made whereby pupils of the schools under the Northumberland County Education Committee may share in the advantages hitherto restricted to town children.

\section{Garden Plants from China}

AN interesting account of the botanical pioneers who first made known the wonderful flora of China, appears in the Journal of the Royal Horticultural Society (62, Pt. 8, 347-351, August 1937). It is mainly a review of a "History of European Botanical Discoveries in China" by E. Bretschneider. The volume is one of the treasures of the Society's Lindley Library, and the article is from the pen of Mr. F. C. Stern. It was not until nearly 400 years after Marco Polo's celebrated journey that Europeans took an interest in the decorative plants of China. Domenicus Parenin first mentioned Wistaria chinensis in 1698, but Father Pierre d'Incarville was probably the first botanical collector in China, about half a century later. It was not until the early part of last century, however, that Chinese plants began to find their way into European gardens; previous collections had been for herbarium material. The work of Dr. Abel, John Reeves, Robert Fortune, Dr. Hance, Father Armand David, Father Jean Marie Delavay, Nicolai Przewalski, Dr. Augustine Henry and other investigators of last century, is described. The account of their collections makes interesting reading, and the plants they introduced are among the greatest contributors to garden beauty.

\section{Tokyo Earthquakes of 1936}

THE last Seismometric Report issued by the Earthquake Research Institute completes the list of earthquakes felt in Tokyo in 1936. In addition to the central station, there are eleven others at various distances up to eighty-four miles from Tokyo, and the records obtained at these stations have enabled the position of the epicentre in all the earthquakes, and the focal depth in all but three, to be determined. The year 1936 is notable on two accounts. It is the year of fewest earthquakes in the district since the network of stations was formed, the number being only 31 , or less than half the average number (64) in the preceding twelve years. Also, more than half the centres were submarine, 14 lying beneath the Pacific Ocean, 4 below Tokyo Bay, and only 13 under land. The depth of focus ranges from $15 \mathrm{~km}$. to 80 $\mathrm{km}$., the average being $45 \mathrm{~km}$. None of the earthquakes was of destructive strength, but in one-that of November 3-the shock was of degree 7 of the Rossi-Forel scale or strong enough to throw down ornaments, vases, etc. Indeed, only four of the 797 earthquakes in the thirteen years were strong enough to cause slight damage to buildings.

\section{The Rubber Research Institute, Malaya}

THE year 1937 will stand out in the history of the Rubber Research Institute, Malaya, as it marks the beginning of a second decade of activity and was the occasion of the occupation of new premises. The purpose and recent work of the Institute are well described in an illustrated booklet and the annual report for 1936, both of which have recently been published (Kuala Lumpur : The Institute). Research work is carried out in four main divisions, botanical, pathological, chemical and soils respectively. Many of the investigations are necessarily made in the field, both at the Institute's Experimental Station and also on, and in co-operation with, a large number of estates throughout Malaya. Retrenchment of staff during the slump and a disastrous fire in 1936 seriously curtailed the activities of the Institute, but a period of expansion is now coming into being, and the rapid development of the advisory work is good evidence that this service is appreciated by estate owners and small-holders alike.

\section{Deep Well Drilling}

AT the Rumanian Branch of the Institution of Petroleum Technologists, on November 27, a discussion was held on problems of deep well drilling. (J. Inst. Pet. Tech., 23; 1937). Mr. G. Elias opened by summarizing the points he considered most influential in successful drilling to depth. Accidents must be avoided at all costs, and the only way to safeguard against them is by provision of suitable equipment, drillers and crews. Mud conditions must be good, as they are invariably reflected in the condition of the well itself. The ultimate cost of the well and drilling time are largely dependent on the selection of a suitable casing programme, and this should be drawn up in new areas immediately the necessary information is available from first wells. An adequate steam supply should be available on the site, not only to reduce the time factor, but also to ensure that a big volume of mud is circulated. Particular care should be taken to see that adequate derricks are employed and also that their foundations are such as to prohibit uneven settling.

\section{Maternal Mortality}

THe Ministry of Health has issued two reports upon this subject, namely, (a) "An Investigation into Maternal Mortality in England", and (b) "Maternal Mortality in Wales" (London : H.M. Stationery Office. 5s. $6 d$., and 2s. 6d., respectively). The national average for maternal mortality has remained for a number of years in the neighbourhood of 4 mothers per 1,000 live births, despite great expansions in maternity services and remarkable improvement in the general health of the community. The provisional figures for 1936 show a slight decline, the rate for that year being less than 4. In many districts in England and in Wales, however, the maternal mortality rate is higher than the average, being 5 or more, and the two reports survey the circumstances that may be responsible for this excessive mortality in England and Wales, and the measures that may be taken to reduce it. The rate is generally higher in industrial areas and lower in rural ones. The first report deals more fully with prevention, and a section is devoted to the subject of abortion. Attempted abortions appear to be frequent and on the increase, as well as to be responsible for a number of deaths from puerperal sepsis. 